\title{
Influence of Sorrel Seed (Hibiscus sabdariffa) meal on haematological and Biochemical indices of broilers chickens in Semi-Arid Region of Nigeria
}

\author{
${ }^{1}$ H. Duwa, ${ }^{2}$ A. Y. Raji and ${ }^{2}$ H. A. Muhammad \\ ${ }^{I}$ Department of Animal Science, University of Maiduguri, P.M.B. 1069, Maiduguri, Borno State, Nigeria \\ ${ }^{2}$ Department of Animal Science, Bayero University, Kano, P.M.B. 3011, Kano State, Nigeria
}

\begin{abstract}
An experiment was conducted to investigate the effect of sorrel seed (Hibiscus sabdariffa) meal on the haematological and biochemical indices of broiler chicken. One hundred and sixty (160) 7 days old chicks (Anak 2000) were used. The birds were randomly allotted to four dietary treatments with 40 birds per treatment and ten (10) birds per replicate. Results of serum biochemistry showed significant differences $(P<0.05)$ among treatments except for blood cholesterol and hydrogencarbonate which showed no significant difference $(P>0.05)$. However, significant difference $(P<0.05)$ were observed for the haematological parameters though $M C H C, M C H$ and $M C V$ did not differ among treatments. The result showed that incorporation of differently processed sorrel seed meal has no negative effect on the blood biochemical indices and haematology.
\end{abstract}

Key words: Haematology, Blood Chemistry, Sorrel Seed Meal, Broilers

\section{Introduction}

The poultry industry in Nigeria, in the last decade, has been greatly affected by high cost of feed [1]. The provision of feed alone has been reported to account for $60-80 \%$ of the total cost in most livestock production in developing countries such as Nigeria $[2,3]$ and this emphasize the interest to develop local feedstuffs. In view of this, there is increased interest by Nigerian livestock farmers to harness unconventional feed ingredients such as sorrel seed meal.

Hibiscus sabdariffa locally known as "Yakuwa" is a well-adapted crop in the semi-arid zone of West Africa including Nigeria and it is generally planted as a border crop. The leaves are used as vegetable and the floral parts in the preparation of "Sobo", a local drink. The stem provides fibre and the seeds are eaten by scavenging poultry [4]. The seed of Hibiscuss sabdariffa is said to have high protein value and it is on account of its protein content that it is well priced for human consumption in French West Africa (Mali, Guinea, Burkina Faso, Cote D' Voire). However, in Nigeria larger quantities of the seeds of this crop are wasted on the farm annually and just enough being collected and stored for planting.

The use of blood examination as a way of assessing the health status of animals has been documented [5]. This is because it plays a vital role in physiological, nutritional and pathological status of organisms [5]. Haematological parameters are those parameters that are related to the blood and blood-forming organs [6]. They range from giving the level of the blood to detecting ailment or disorders through them. It had been reported that biochemical changes as a result of toxins have effects on haematological parameters [7]. The objective of this study was to investigate the effect of sorrel seed meal on the blood components of broiler finisher birds under semi-arid environment.

\section{Materials And Methods}

\subsection{Experimental site}

The study was conducted at the Poultry Production Unit (PPU) of Borno State Ministry of Agriculture and Natural Resources Maiduguri. The farm had standard deep litter houses. The study area lies between Latitude $11^{0}-15^{0}$ inch North and longitude $30^{\circ}$ - 05 inch East and had an altitude of $354 \mathrm{~m}$ above sea level [8]. It is characterized by hot and dry climate and short duration of erratic rainfall $(3-4)$ months per annum and a long period of dry season. Ambient temperatures are low in December to January ranging from $15-19^{\circ} \mathrm{C}$ and high in March to June, ranging from $33-44^{0} \mathrm{C}$ and low relative humidity ranging from $5-43.5 \%$ [8].

\subsection{Experimental stock/plant}

Source and processing of sorrel seeds:-

The sorrel seeds used in this study were procured locally around Maiduguri and processed as follows:

i. $\quad 25 \mathrm{~kg}$ of raw sorrel seeds were cleaned and milled and incorporated into the diets of broilers. 
ii. $\quad 25 \mathrm{~kg}$ of sorrel seeds were cleaned and roasted for 40 minutes in frying pan at $100^{\circ} \mathrm{C}$ and cool under shed for a day, then milled and incorporated into the diets of broilers.

iii. $\quad 25 \mathrm{~kg}$ of sorrel seeds were cleaned and boiled in water for 30 minutes at $100^{\circ} \mathrm{C}$ in an aluminum pot, sundried for three days, then milled and incorporated into the diets of cockerels.

iv. $\quad 25 \mathrm{~kg}$ of sorrel seeds were cleaned and soaked in water for 12 hours in a plastic basin, sun dried for three days then milled and incorporated into the diets of cockerels.

\subsection{Experimental birds and management}

One hundred and sixty (160) 7 days-old Anak 2000 broiler chicks were used for the study in a completely randomized design. The chicks were individually weighed and randomly selected and allocated to each of the four different types of processing methods. Each type of processing method consists of forty birds with 10 birds per replicate. Chicks were brooded under 100watts electric bulbs. The experiment lasted for seven weeks. All management were adhered to The birds were vaccinated against Gumboro, at two and five weeks of age while New castle disease vaccine (Lasota) was administered at three weeks of age. Antistress was given each time after administration of drugs. Feed and water was given ad libitum.

The processing methods comprised of four diets which contain raw sorrel seed, (RSSM) group1 [gp1], roasted sorrel seed (ROSS)group2[gp2], boiled and dried sorrel seed (BDSS)group3[gp3] and soaked and dried sorrel seed (SDSS)group4[gp4] in diets as shown in Table 1.

\subsection{Chemical analysis}

The experimental diets were analyzed for dry matter (DM), Crude protein (CP), crude fibre (CF), ether extract (EE), ash according to [9] while tannin was determined using the method of Polshettiwar et al. [10].

\subsection{Haematological Studies and Blood Chemistry}

At the end of the trial, three birds per replicate were randomly selected. A set of blood samples was collected into EDTA bottles for haematological evaluation while another set of blood samples were collected without anticoagulant for blood chemistry evaluation. Parameters measured under haematological studies included packed cell volume (PCV), red blood cell count (RBC), white blood cell (WBC) count. The blood constants, mean corpuscular haemoglobin concerntration (MCHC) and Mean corpuscular haemoglobin (MCH) were computed using appropriate formulae as described by Jain [11]. The bottles were kept in cooled cotton prior to analysis. Haematological parameters and blood chemistry were evaluate according to the procedure described by Davis and Lewis [12]. The serum biochemical assay was carried out using standard chemical procedures: Total serum protein by Golgberg refractometer method [13], albumin by Bromocresol green (BCG) method [14], creatinine [15], urea nitrogen [16], serum glucose [17], Sodium ions and Potassium ions by flame photometry [18] serum enzymes by spectrophotometric method [19].

\subsection{Statistical analysis}

Data obtained was subjected to analysis of variance. Where significant differences occurred, the means will be separated using Duncan multiple range F-test of the SAS [20] options.

\subsection{Blood biochemical indices}

\section{Results}

Table 3, showed the values for all the serum biochemical indices. The serum biochemical indices indicated significant $(\mathrm{P}<0-05)$ differences in favour of birds fed on boiled sorrel seed meal[gp3] but blood calcium and alkaline phosphate indicated significance $(\mathrm{P}<0.05)$ difference in birds fed on raw sorrel seed meal[gp1]. The blood cholesterol, $\mathrm{HCO}_{3}$ and glutamic oxaloacetic transaminase indicated no significant $(\mathrm{P}>0.05)$ difference among the types of different processing methods. The result indicated that no effect of tannin in birds fed on boiled sorrel seed meal[gp3] compared to birds fed on raw, roasted and soaked sorrel seed meal[gp1,2\&4] respectively.

\subsection{Haematological parameters}

Data on the haematological parameters are shown in Table 4. There were significant $(P<0.05)$ differences among the types of different processing methods for all the parameters. The haemetological indices were red blood cell (RBC), white blood cell (WBC), haemoglobin (Hb), mean corpuscular haemoglobin concentration (MCHC), mean corpuscular haemogbin $(\mathrm{MCH})$, mean corpuscular volume, $(\mathrm{MCV})$ and packed cell volumes $(\mathrm{PCV})$. The significant $(\mathrm{P}<0.05)$ difference were indicated in birds fed on boiled and soaked sorrel seed meal[gp3\&4]. The MCHC, MCH and MCV indicated no significant $(\mathrm{P}<0-05)$ difference among the types of different processing methods. These parameters were used to measure the size and haemoglobin content of the erythrocytes and values are useful in diagnosing various forms of aneamia. 


\section{Discussion}

Blood protein values showed significant difference among the types of processing methods. The significantly higher value of blood protein was indicated in birds fed on boiled sorrel seed meal. The values obtained in this study were within the normal range of serum protein $(5.00-7.00 \mathrm{~g} / \mathrm{dl})$ reported by Anon [21] and 4.55 to $6.46 \mathrm{~g} / \mathrm{dl}$ reported by Udoyong et al. [22] but lower than 8.32 to 8-70 g/dl reported by Njidda et al. [23]. Higher values indicate that there is enzyme hydrolysis of dietary proteins and explained that the blood pool serves as a major source of aminoacids needed for the synthesis of proteins [24, 23]. This observation showed that the protein level in the diet was sufficient to sustain or support the normal protein levels in the blood. It should be noted that the protein levels in the diets were similar. Blood albumin values indicated significant difference among the different processing methods with birds fed on boiled sorrel seed meal[gp3] having the highest value over birds fed on raw, roasted and soaked sorrel seed meal[gp1,2\&4]. This could be the reason why they have comparable total protein content among the different groups. This observation agreed with the observation of Anon [21] and Allison [25] who reported changes in protein reserve in animal as indicated by serum total protein to be associated with alteration in the albumin fraction.

Blood globulin values also indicated significant difference among the different processing methods with higher significant values in birds fed on boiled sorrel seed meal[gp3]. The result of the blood globulin which was the value obtained after the subtraction of albumin from total serum protein showed that the values obtained could be attributed to the comparable utilization of protein in diets as reflected by the feed conversion ratio (Table 3). Furthermore, the proteins in the diet may be of comparable quality. For instance in pigs fed raw mucuna beans meal; [26] observed the dependence of blood proteins on the quantity and quality of dietary proteins.

Blood cholesterol showed no significant difference among the processing methods. The observed similarity in blood cholesterol was expected because of the comparable dry matter intake of the different diets. The diets contained similar crude fat levels which may invariably lead to comparable dietary fat intake. The values were lower than those reported by (Ogbuewu et al. [1] but within the range reported by Njidda et al. [23]. Prolonged high levels of blood cholesterol may result in its deposition on the walls of the blood vessels and these deposits may eventually harden to atheroschlerotic plaque, these may block important blood vessels and result in a myocardial infraction.

Blood calcium values revealed significant difference among the different processing methods. The blood calcium levels are the most important factors in the formation and maintenance of the bones. Minerals are known to be part of hormones and as activators of enzymes [27]. The values recorded in this study were similar to those recorded by Anon [21]. The reasons for the significant difference may be attributed to calcium ratio of the diet. The evidence of calcium and phosphorus deficiency may be obtained from an analysis of blood serum, which would show content lower than normal [28].

The values of sodium and potassium recorded in this study ranged from, 131.73 to $138.00 \mathrm{mmol} / \mathrm{l}$ and 2.15 to $3.75 \mathrm{mmol} / \mathrm{l}$ respectively and this differed significantly among the different processing methods, the significant difference could be as a result of the processing method which boiling appear to be the best for sorrel seeds. Sodium and potassium are known to regulate osmotic pressure, maintain membrance potentials and acid-base balance and transmit nerves impulses. Sodium and potassium deficiency affect the tubes of kidney resulting in an inability to concentrate urine. It also causes alterations of gastric secretions and intestinal motility $[29,30]$.

Serum creatinine revealed significant different among the types of different processing methods. Birds fed on boiled sorrel seed meal[gp3] had the lowest value. The highest value was in birds fed on soaked sorrel seed meal[gp4] followed by birds fed on roasted and raw sorrel seed meal[gp2\&1]. The level of serum creatinine signals the extent of muscle wastage [1]The significant increase in serum creatinine of birds fed on raw, roasted and soaked sorrel seed meal gives evidence to the fact that the birds were not surviving at the expenses of body reserves. Hence there was no weight losses observed in the study, while the lower value in birds fed on boiled sorrel seed meal[gp3] may be as a result of processing method.

The similarities on conjugated bilirubin value of birds in all the groups ruled aut the possibility of liver damage which is usually associated with increased serum conjugated bilirubin [31]. The results of this study is similar to the findings of Ogbuewu et al. [1] who reported values ranging from 0.60 to $0.70 \mathrm{mg} / \mathrm{dl}$ of CBL. Other serological indices such as blood cholesterol, $\mathrm{HCO}_{3}$ and glutamic oxaloacate transaminase indicated no significant difference among the different processing methods. The significant difference observed for most of the serological indices are indication of less anti-nutritional factors in the diet formulated with boiled sorrel seed meal [32].

Haematological parameters

There were significant differences among the different processing methods for all the haematological parameters except mean corpuscular haemoglobin concentration (MCHC), mean corpuscular hemoglobin $(\mathrm{MCH})$ and mean corpuscular volume (MCV) which did not differ significantly among of different processing 
methods. The range for PCV $(25.00-36.50 \%)$ in the different types of processing methods fell within the normal range of values (30-40\%) [33] and 28.00 to $30.70 \%$ reported by Ogbuewu et al. [1]. The lowest value of $(25.00 \%)$ obtained in birds fed on raw sorrel seed meal[gp1] was inferior to the other processing methods. This could be attributed to the high-tannin content of the diets raw sorrel seed meal. Tannins are known to lower dry matter and protein digestibility [34]. The range $8.22-12.45 \mathrm{~g} / \mathrm{dl}$ of $\mathrm{Hb}$ values were in line with the range 8-13 g/dl [35] for all the different processing methods. Awomiyi et al., [36] reported that haemoglobin and heamatocrits values are influenced by temperature. The range $\left(3.00-5.25 \times 10^{6} / \mathrm{dl}\right)$ of $\mathrm{RBC}$ was within the normal range of (3-6 x 10\% $/ \mathrm{dl})$ for chicken [37]. The RBC values were higher than the values reported by Njidda et al. [23] for broilers of similar ages in the same environment. The WBC values range $\left(14.00-19.25 \times 10^{3} / \mathrm{dl}\right)$ tally with the range $\left(9-58 \times 10^{3} / \mathrm{mm}\right)$ reported by Oluremi and Sridhar [34]. According to Freeman [38] about $90 \%$ of the total leucocytes in the blood of chickens are lymphocytes and heterophyls. The heterophyls, lymphocytes ratio in chickens increase linearly as stressor order increases [38, 39]. The total WBC counts have been reported to increase with stressor applied on the chickens [39]. The range $21.8-23.72 \mathrm{~g} / \mathrm{l}$ of MCHC, 24.50 $-27.00 \mu \mathrm{g}$ of MCH and $126.25-127.75 \mathrm{ft}$ of MCV for birds fed on raw, roasted, boiled and soaked sorrel seed meal respectively agreed with the report of Swenson [39] that normal erythrocyte indices for chickens ranged between 21 - 23g/l for MCHC, $25.00-27 \mu \mathrm{g}$ for $\mathrm{MCH}$ and 115 - 127Ft for MCV. These parameters were used to measure the size and haemoglobin content of erythrocytes and values are useful in diagnosing various forms of aneamia.

\section{Conclusion}

The major anti- nutritional factors identified in the sorrel seed meal are tannins which are known to impair feed intake, nutrient digestibility and growth of poultry and young animals. Boiling as a processing method appears to be a more effective method of tannins reduction in sorrel seed than roasting and soaking in water. The result of this study also reveals that inclusion of sorrel seed meal using different processing methods have no negative effect on the health status of the broiler chickens.

\section{Acknowledgment}

The authors wish to thank Dr. A. A. Njidda of Bayero University, Kano for his editorial support.

\section{References}

[1]. Ogbuewu, I.P., M.C. Uchegbu, C.C. Ezuma, and M. N. Opara, 2010. Physiological responses of finisher broilers to yam peel meal: haematology and serum biochemistry. EJEAFChe 9(10): 1657-1664

[2]. Igboeli, G. 2000. Animal Production and Agriculture in the new millennium. Book of Proc. 25th Ann. NSAP. Conf. pp. 1 - 3.

[3]. Esonu, B. O. 2000. Animal nutrition and feeding: A functional approach. Rukzeal and Rukson Association Memory Press, Owerri, Nigeria.

[4]. Philips, T. A. 1977. An Agricultural Textbook. Longman Group Limited, London. 89 - 101.

[5]. Muhammad, N.O., A.O. Adeyina and O.M. Peters, 2000. Nutritional evaluation of fungi treated cocoa bean shell. Nigerian J. Pure and Appl. Sci., 5: 1059-1064.

[6]. Stenesh, J. 1975. Dictionary of Biochemistry. Wiley-Interscience Publication, London, pp: 137.

[7]. Karnish, A.R. 2003. Immune regulation in health and disease. Academic Press. San Diego, pp: 121-127.

[8]. Alaku, S. O. 1983. Body and carcass losses in goats during the advance dry period of the West Africa Sahelian Zone. Journal of Animal Science. 79: 504 - 513.

[9]. AOAC 2002. Official Methods of Analysis of the Official Analytical Chemists, $17^{\text {th }}$ ed.(Horwitz,W.,ed.), Association of Official Analytical Chemists, Washington DC.

[10]. Polshettiwar, S. A., R.O. Ganjiwale, S.J. Wadher, P.G. Yeole, 2007. Spectrophotometric estimation of total tannins in some ayurvedic eye drops. Indian J. Pharmaceutical Sci. 69 (4):574-576.

[11]. Jain, N.C. 1986. Veterinary Haematology.4th edition. Baillere, Tindall. Pp. 297.

[12]. Davis, J. V. and S.M. Lewis, 1991. Practical Haematology. $8^{\text {th }}$ edition, Long Group Ltd. Pp. 21-68

[13]. Kohn, R.A. and M.S. Allen, 1995. Enrichment of proteolytic activity relative to nitrogen in preparations from the rumen for in vitro studies. Anim. Feed Science and Technology. 52(1/2):1-14.

[14]. Peters, T., C.T. Biomont, and B.T. Doumas, 1982. Protein (total protein) in serum, urine and cerebrospinal fluid, albumin in serum: In selected methods of clinical chemistry, volume 9. W.R. Faulkner and S. Meites (eds.) Washington D.C. American Association of Clinical Chemist.

[15]. Boisness, R.W. and H.H.J. Taussky, 1985. Determination of creatinine in plasma and urine. J. Biol. Chem., 158 -581

[16]. Baker, F. J. and R.E. Silverton, 1985. Introduction to Medical Laboratory Technology, 6th edition. Butterworth, England.

[17]. Toro, G. and A. Ackerman, 1979. Practical chemical chemistry, 1st edition. Little Brown and Company, Boston, pp. 237-238.

[18]. Schales, O. and S.S. Schales, 1941. A simple and accurate method for the determination of chloride ion in biological fluid. J. Biol. Chem. 140:874.

[19]. Rej, R. and M. Hoder, 1983. Aspartate aminotransferase. In: Methods of enzymatic analysis. 3rd ed. H.U. Berg Meyer and M. Grassl (eds.). Weinheim Verlag-Chemie, 1(3): 416 - 433.

[20]. Statistical Analysis System Institute Inc. 1988. SASSTAT programme, Cary, NC: SAS Institute Inc. 1988.

[21]. Anonymous, 1980. Guide to the Care and Use of Experimental Animals Vol. 1. Ottawa, Ontario, Canada, Canadian Council on Animals care. $85-90$.

[22]. Udoyong, A. O., A. Kibon, S. M. Yakubu, B. Yakubu, C. Augustine and L. Isaac, 2010. Haematological responses and serum biochemistry of broiler chicken fed graded levels of enzyme (Maxigrain) supplemented cassava a peel meal (CPM) based diets. Global J. Biotech. Biochem. 5(2): 116-119. 
[23]. Njidda, A. A., J.U. Igwebuike, A.A. Ngoshe, and A.O. Tijjani, 2006. Effect of substituting maize with graded levels of cane molasses on the performance of broiler finisher birds in the semi- arid region of Nigeria. J. Sustainable Agric. Environ. 8 (1): 1-13

[24]. Scott. A. 1970. Absorption of carbohydrate and protein metabolism. In: Duke's Physiology of Domestic Animals. $18^{\text {th }}$ edn. (Swenson, M.J. edns). Cornell University Press Limited, London.

[25]. Allison, J.B. 1955. Biological evaluation of proteins. Physio, Rev.35: $664-669$.

[26]. Esonu, B.O., O.O. Emenalon, A.B.I. Udedibie, U. Herbert, C.F. Ekpor, I.C. Okoli, and F. C. Iheukwumere, 2001. Performance and blood chemistry of weaner pigs fed raw mucuna bean (velvet bean) meal. Tropical Animal Production Investment. 4: 49 - 54.

[27]. National Research Council (NRC), 1977. Nutrient Requirements of Poultry. National Academy of Science, Washington, D.C., No.1, $2-10$.

[28]. McDonald, P., R.A. Edward, and J.F.D. Greenhalgh, 1994. Animal Nutrition $4^{\text {th }}$ ed. English Language Book Society and Longman, England $548-594$.

[29]. Follis, R.H. Jr., E. Orient-Keillis, and E.V. McCollum, 1942. The production of cardiac and renal lesions in rats by a diet extremely deficient in potassium. Animal J. Pathology. 18: 29 - 39.

[30]. Srteenten, D.H.P and E.M.V. Williams, 1952. Lack of cellular potassium as a cause of intestinal paralysis in dogs. J. Physiology. 118: $149-170$.

[31]. Cheesbrough, M. 2000. District Laboratory Practice in Tropical Countries. Part 2, Cambridge University Press.

[32]. Price, M.L., LG. Butler, J.C. Rogler, and W.R. Featherston, 1979. Overcoming the nutritionally harmful effects of tannin in sorghum grains by treatment with inexpensive chemicals. J. Agric. Food Chemistry. 27: $441-445$.

[33]. Siegmind, K.H. 1979. Strain differences in poultry. Influence of strain and diet on haematological trait. Laboratory Animal. 17: 7 12.

[34]. McSweeny, C.S., B. Palmer, D.M. McNeill, D.O. Krause, 2001. Microbial interactions with tannins: nutritional consequences for ruminants. Animal Feed Science and Technology 91, 83-93.

[35]. Oluremi O.I.A. and M.K.C. Sridhar, 2004. Effects of domestic effluent utilization on the blood characteristics of grower pullets. Nigerian J. Animal Production. 31 (2): $200-206$.

[36]. Awoniyi , T.A.M., V.A. Aleto, I.A. Adebayo, and R.O. Oyekunle, 2000. Observations on some erythrocyte indices of broiler chickens raised on maggot meal-based diets. In: Ukachuku, S.N.; Ibeauchi, J.A., Ibe, S.N.; Ezekwe, A.G. and Abasiekong, S.F. (eds), Animal Production in the New Millenium: Challenges and options, pp184-187 Proceedings of the $25^{\text {th }}$ Annual Conference of Nigerian Society of Animal Production, Michael Okpara University of Agriculture, Umudike, Nigeria, 19 - 23 March, 2000.

[37]. Madubuike, F. N. and B.U. Ekenyem, 2006. Haematology and Serum Biochemistry Characteristics of Broiler Chicks Fed Varying Dietary Levels of Ipomoea asarifolia Leaf Meal. International J. Poultry Science. 5(1): 9-12.

[38]. Freeman, B.M. 1971. The corpuscles and physiological characteristics of blood. In: Physiology and Biochemistry of Domestic Fowl (ed. Bell, D.J. and Freeman, B.M.) Vol. II. Academic Press Inc; London. 841 - 852.

[39]. Swenson, M.J. 1993. Physiologic properties, cellular chemical constituents of blood. In: Dukes Physiology of Domestic Animals 8th Ed. (M.J. Swenson edn.). Comstock Publishing Associates, Cornel University Press. Ithaca and London Pp. 20 - 61

Table 1:Proximate composition, Tannin proportion and reduction level of differently processed sorrel seed meal

\begin{tabular}{lllll}
\hline Parameter (\%) & gp 1 & gp 2 & gp 3 & gp 4 \\
\hline Dry matter & 94.30 & 94.20 & 90.40 & 91.55 \\
Moisture content & 5.70 & 5.80 & 9.60 & 8.45 \\
Crude protein & 26.00 & 25.40 & 27.10 & 25.85 \\
Crude fibre & 15.00 & 14.00 & 13.10 & 15.50 \\
Ether extract & 16.00 & 19.00 & 23.00 & 16.00 \\
Ash & 7.00 & 8.00 & 7.00 & 9.00 \\
Nitrogen free extract NFE) & 36.00 & 33.60 & 29.80 & 33.65 \\
Tannins level \% & 2.50 & 2.00 & 0.80 & 1.60 \\
\% Reduction of tannins & - & 20.00 & 68.00 & 36.00 \\
RSS=Raw Sorrel seed; ROSS= & Roasted & Sorrel & seed; BDSS=Bolled and dried Sorrel seed;
\end{tabular}

SDSS=Soaked and dried sorrel seed

Table 2:Proximate composition of treatment diets containing differently processed sorrel seed meal at the finisher phase.

Parameter $(\%)$

\section{Types of processing methods}

\begin{tabular}{lllll} 
& gp 1 & gp 2 & gp 3 & gp 4 \\
\hline Dry matter & 9.2 .80 & 93.40 & 92.60 & 93.40 \\
Moisture content & 7.20 & 6.60 & 7.40 & 6.60 \\
Crude protein & 19.40 & 19.50 & 19.60 & 19.00 \\
Crude fibre & 7.00 & 8.50 & 6.00 & 7.10 \\
Ether extract & 5.00 & 5.50 & 7.00 & 6.50 \\
Ash & 3.50 & 2.00 & 2.00 & 2.50 \\
Nitrogen free extract (NFE) & 65.10 & 64.40 & 65.40 & 64.90
\end{tabular}


RSS= Raw sorrel seed; ROSS= Roasted sorrel seed; BDSS=Boiled and dried sorrel seed;SDSS:Soaked and dried sorrel seed

Table 3:Blood chemistry of broiler chickens fed raw and differently processed sorrel seed meal (SSM)

\begin{tabular}{|c|c|c|c|c|c|}
\hline \multirow[t]{2}{*}{ Parameters } & \multicolumn{4}{|c|}{ Types of processing methods } & \multirow[b]{2}{*}{ SEM } \\
\hline & gp 1 & gp 2 & gp 3 & gp 4 & \\
\hline Blood Protein $(\mathrm{g} / \mathrm{dl})$ & $4.20^{6}$ & $2.82^{\mathrm{b}}$ & $7.72^{\mathrm{a}}$ & $5.65^{\mathrm{b}}$ & $0.327^{*}$ \\
\hline Blood albumin (g/dl) & $2.70^{\mathrm{b}}$ & $2.60^{\mathrm{b}}$ & $4.07^{\mathrm{a}}$ & $2.32^{\mathrm{b}}$ & $0.157 *$ \\
\hline Globulin $(\mathrm{g} / \mathrm{dl})$ & $2.80^{\mathrm{c}}$ & $2.40^{\mathrm{c}}$ & $5.35^{\mathrm{a}}$ & $4.00^{\mathrm{b}}$ & $0.295^{*}$ \\
\hline Blood Cholesterol (mg/dl) & 3.64 & 3.23 & 3.64 & 3.10 & 0.237 \\
\hline Urea $(\mathrm{mg} / \mathrm{dl})$ & $9.62^{\mathrm{c}}$ & $17.22^{\mathrm{b}}$ & $29.00^{\mathrm{a}}$ & $11.00^{\mathrm{bc}}$ & $1.965 *$ \\
\hline Creatinine $(\mathrm{mmol} / \mathrm{l})$ & $42.27^{\mathrm{a}}$ & $45.51^{\mathrm{ab}}$ & $38.50^{\mathrm{a}}$ & $55.00^{\mathrm{c}}$ & $5.923 *$ \\
\hline Sodium $\left(\mathrm{Na}^{+}\right)(\mathrm{mmol} / \mathrm{l})$ & $1.31^{\mathrm{b}}$ & $1.31^{\mathrm{b}}$ & $1.38^{\mathrm{a}}$ & $1.34^{\mathrm{ab}}$ & $1.474 *$ \\
\hline Potassium $\left(\mathrm{K}^{+}\right)(\mathrm{mmol} / \mathrm{l})$ & $2.36^{\mathrm{b}}$ & $2.42^{\mathrm{b}}$ & $3.75^{\mathrm{a}}$ & $2.15^{\mathrm{b}}$ & $0.303 *$ \\
\hline Calcium $\left(\mathrm{Ca}^{2+}\right)(\mathrm{mmol} / \mathrm{l})$ & $10.55^{\mathrm{a}}$ & $9.65^{\mathrm{c}}$ & $9.82^{\mathrm{b}}$ & $9.55^{\mathrm{c}}$ & $2.2396^{*}$ \\
\hline $\mathrm{HCO}_{3}(\mathrm{mmol} / \mathrm{l})$ & 23.00 & 21.25 & 25.75 & 22.00 & 1.490 \\
\hline Bilirubin (mg/dl) & $0.82^{\mathrm{a}}$ & $0.51^{\mathrm{b}}$ & $0.85^{\mathrm{a}}$ & $0.40^{\mathrm{b}}$ & $0.813 *$ \\
\hline Bilirubin conjugated (mg/dl) & $0.20^{\mathrm{a}}$ & $0.20^{\mathrm{b}}$ & $0.38^{\mathrm{a}}$ & $0.23^{\mathrm{b}}$ & $0.035^{*}$ \\
\hline Alkaline phosphate $(\mu / 1)$ & $66.60^{\mathrm{b}}$ & $58.82^{\mathrm{b}}$ & $17.75^{\mathrm{a}}$ & $45.52^{\mathrm{c}}$ & $2.953 *$ \\
\hline Glutamic oxaloacetic & & & & & \\
\hline transaminase $(\mathrm{SGOT})(\mu / \mathrm{l})$ & 10.50 & 11.50 & 10.70 & 9.75 & 0.635 \\
\hline $\begin{array}{l}\text { Glutamic pyruvic } \\
\text { transminase (SGPT) }(\mu / 1)\end{array}$ & $10.75^{\mathrm{c}}$ & $11.50^{\mathrm{b}}$ & $10.97^{\mathrm{c}}$ & $70.75^{\mathrm{a}}$ & $1.935^{*}$ \\
\hline
\end{tabular}

a, b, c, Means within the same row bearing different superscript differ significantly $(\mathrm{P}<0.05)$; SEM=Standard Error of Means; NS=Not significant $(\mathrm{P}>0.05) ; *=$ Significant difference $(\mathrm{P}<0.05)$; RSS $=$ Raw sorrel seed; ROSS=Roasted sorrel seed; BDSS=Boiled and dried sorrel seed; SDSS=Soaked and dried sorrel seed

Table 4: Blood parameters of broilers chickens fed raw and differently processed sorrel seed meal

\begin{tabular}{|c|c|c|c|c|c|}
\hline \multirow[t]{2}{*}{ Parameters } & \multicolumn{5}{|c|}{ Types of processing methods } \\
\hline & gp 1 & gp 2 & gp 3 & gp 4 & SEM \\
\hline $\mathrm{RBC} \times 10^{6} / \mathrm{mm}^{3}$ & $3.00 \mathrm{c}$ & $3.21 \mathrm{c}$ & $5.25 \mathrm{a}$ & $4.10^{\mathrm{b}}$ & $0.114 *$ \\
\hline WBC $\times 10^{3} / \mathrm{mm}^{3}$ & $14.00^{\mathrm{c}}$ & $14.25^{\mathrm{c}}$ & $19.25^{\mathrm{a}}$ & $18.00^{\mathrm{b}}$ & $0.381 *$ \\
\hline $\mathrm{Hb}(\mathrm{g} / \mathrm{dl})$ & $8.22^{\mathrm{b}}$ & $12.45^{\mathrm{a}}$ & $12.37^{\mathrm{a}}$ & $9.25^{\mathrm{b}}$ & $0.328 *$ \\
\hline $\mathrm{MCHC}(\%)$ & $21.80^{\mathrm{a}}$ & $22.55^{\mathrm{a}}$ & $23.72^{\mathrm{a}}$ & $22.52^{\mathrm{a}}$ & $0.388^{\mathrm{NS}}$ \\
\hline $\mathrm{MCH}(\mathrm{pg})$ & $25.50^{\mathrm{b}}$ & $25.50^{\mathrm{ab}}$ & $27.00^{\mathrm{a}}$ & $25.75^{\mathrm{ab}}$ & $0.578^{\mathrm{NS}}$ \\
\hline $\mathrm{MCV}(\mathrm{ft})$ & $126.25^{\mathrm{a}}$ & $127.25^{\mathrm{a}}$ & $124.25^{\mathrm{a}}$ & $127.75^{\mathrm{a}}$ & $1.037^{\mathrm{NS}}$ \\
\hline $\mathrm{PCV}(\%)$ & $25.00^{\mathrm{c}}$ & $31.50^{\mathrm{a}}$ & $36.50^{\mathrm{a}}$ & $32.25^{\mathrm{b}}$ & $0.589 *$ \\
\hline
\end{tabular}

